\title{
Ecofeminism Literary Criticism and its Application in British and American Literature Teaching
}

\author{
Peng Zhang ${ }^{1, ~ a ~, ~ H u i ~} \mathrm{Li}^{2, \text { b }}$, Jiarong Hao ${ }^{3, \mathrm{c}}$, Xiuli Gou ${ }^{1, \mathrm{~d}}$ \\ ${ }^{1}$ College of Foreign Languages, Bohai University, Jinzhou, 121013, China \\ ${ }^{2}$ Teaching and Research Institute of Foreign Languages, Bohai University, Jinzhou, 121013, China \\ ${ }^{3}$ College of Public Foreign Languages, Jinzhou Medical University, Jinzhou, 121001, China

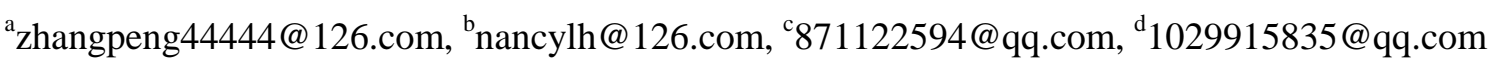

Keywords: ecofeminism; literary criticism; British and American literature; teaching application

\begin{abstract}
Ecofeminist literary criticism is different from general literary criticism. It has a broader vision and extends to all aspects of life contained in literature. It involves the aspects of nature, gender, class and race in literature and their interrelationships. The discussion of relationship is the content of ecological feminist literary criticism. The ecofeminist literary criticism is applied to the teaching of English and American literature, and the female literary criticism theory is used to analyze the works properly, which makes the vision of ecological literary criticism expand and deepen. The specific teaching methods include mining and rereading ecological texts in British and American literary works, introducing literary criticism into the conscious creation and cultural life of literature, and combining various literary criticism theories to improve teaching effects.
\end{abstract}

\section{Introduction}

"Ecological feminism" was first proposed by the French feminist scholar Francoise d'Eaubonne in "Le Feminisme ou la Mort". The core idea is that human oppression of women is directly related to the oppression of nature. A series of ecological disasters at the end of the twentieth century led to the development of ecofeminism. Ecofeminism is a combination of ecological movements and feminist movements. It advocates linking "natural discrimination" with "sex discrimination" and trying to find a special between demeaning women and demeaning nature that prevail in society. The relationship opposes the oppression of "vulnerable groups" such as nature, women and other races under the patriarchal worldview and binary thinking, and advocates the establishment of a new type of relationship between people, people and nature that is equal, harmonious and interdependent. In recent years, with the continuous promotion and deepening of ecological research, ecofeminism literary criticism has received increasing attention.

British and American literature is an important part of foreign literature, and it is an important professional course in the teaching of English majors in higher education institutions in China. In the traditional English and American literature teaching, the main focus is on the universally recognized single theme of the writers and works, focusing on the old programs, lacking innovation and pioneering consciousness. The "Syllabus for English Majors in Colleges and Universities" points out that the purpose of the literature course is to develop students' ability to read, appreciate and understand the original works of English literature, to master the basic knowledge and methods of literary criticism, and to promote the basic skills of students by reading and analyzing English and American literature. The improvement of humanities quality enhances students' understanding of Western literature and culture. The existing English and American literature materials lack the application of new literary criticism theory.

Feminist literary criticism has a greater influence on literary standards than any other critical theory, and is one of the most innovative forces in modern critical theory. Ecofeminist criticism is the product of the organic combination of feminist criticism and ecological criticism. The ecofeminist literary criticism further expands the field of literary studies, further transforms literary 
studies, and extends the reach of literary studies to the natural world outside human society that has long been forgotten by human beings, studying literature and the natural environment. The purpose of mutual criticism is to awaken people's awareness of ecological protection through literary research, realize the harmonious development between man and nature, and thus establish a society in which people and nature live in harmony, species equality and ecological balance, in order to realize human economic and social. Continue to develop. Western ecological feminist literary criticism, which was born under the intensified ecological crisis, not only provides a new perspective for the teaching of English and American literature, but also brings new vitality to the deteriorating nature.

\section{Ecological Feminist Literary Criticism and the Teaching of English and American Literature}

As a very influential literary criticism paradigm, ecocriticism is based on ecological philosophy, to explore the relationship between literature and the natural environment, to see human thoughts and culture and many other issues. Eco-literary critics absorb theoretical nourishment from the disciplines of ecology, feminism, ethics and religion, and go all out to develop their own subject areas in various fields that contain ecological consciousness and the relationship between man and nature, making ecological literary criticism The vision is constantly expanding and deepening. The ultimate goal of ecocriticism is to guide the ideological and cultural criticism through literary works, which is guided by the ecological holistic view and the concept of harmony, thus revealing how human culture affects nature and ecology. Because only from the roots and from the deeper level of ideology and culture, the ecological crisis can be slowly eliminated. As Donald Worcester said, the real cause of the global ecological crisis is not the internal mechanism of the ecosystem, but The impact of human thought, culture, and ethical systems. Therefore, it is particularly urgent to integrate the awareness of ecocriticism into the teaching of English and American literature.

Introducing feminist literary criticism into the English and American literature classes is not to exclude male students in the classroom and treat them as aliens. Feminist literary criticism has developed to the present stage. It has not only aimed at the equality of men and women, but has devoted itself to giving full play to the potential and role of women and creating a world in which men and women live in harmony. Using feminist literary criticism to analyze works and literary history can help boys to correctly view the role of women in human history, cultural history, and everyday life, and make them aware of the unfair suppression of women in history and even in real life. How this kind of suppression hinders the free communication between men and women, and ultimately how to hinder the harmonious development of human civilization. Feminist literary criticism is closely related to social practice. It plays an important role in students' self-reflection, self-exploration and establishment of correct gender concepts. The diversification of values brought by the current market economy has confused people who are in it. Under the stereotypes of outlook on life and values, college students introduce feminist literary criticism in the classroom, which provides students with a deep understanding of life and independent social phenomena. Critical thinking, establishing a correct outlook on life and values, and grasping its own subjective status all have positive significance.

\section{Feminist Literary Criticism Theory Applied to English and American Literature Classes}

Introducing feminist literary criticism theory into English and American literature classrooms, using female literary criticism theory to analyze works, so that students can fully understand the discrimination and suppression of women in human history and cultural history, and correctly view the role of women in real life. It helps students to correctly establish gender concepts and values, and to understand the essence of gender identity cognition. The analysis of characters in English and American literary works is passed on to independent critical thinking on realistic phenomena, eliminating the traditional gender binary parameter system and perfecting students. A diverse gender perception of real life. Different ways of thinking between male writers and female writers 
due to gender differences produce different worldviews and outlooks on life. These differences are reflected in literary works. When the teacher guides the students to read the work, the students are encouraged to use the culture attached to the work to analyze and understand the unique connotation of the work. In terms of the connection between literary works and reality, students are encouraged to form open-minded thinking and look at the practice of female equality in society from multiple perspectives.

The classroom structure of English and American literary works is not the relationship between teachers' leadership and control of students, but the common energy of teachers and students. It is necessary to establish a teaching model in which teachers and students participate in discussions, and participate in discussions and publish their own opinions in order to achieve maximum Teaching effect. When applying feminist literary criticism to the teaching of literary works, in the historical and cultural context, the effective general knowledge between empathy and writers can be solved, the problem of character analysis from the reality can be solved, and the students' critical thinking ability can be cultivated. Literary theory is relatively abstract, and can not be taught as simple knowledge, but applied to the interpretation of literary works, so that literary theory can really play its role. Some classic British and American literary works and related literary criticism articles should be selected. Teachers should combine the historical situation of literary works, consult the materials, organize and discuss after the students read, let the students analyze the character characteristics from their respective angles, and use literary theory to analyze and clarify themselves. the opinion of.

\section{Mining and Rereading Ecological Texts in British and American Literary Works}

The British and American literature is profound and profound, and the classic works are even more numerous. "There is no literary work, no matter where it originates, it cannot be interpreted ecologically." Whether it is a romantic poetry with a rich view of nature or a novel full of tension in the modernist period, whether it is an ecological literature that conveys an ecologically holistic view or an anti-ecological literature with complex contradictions, it can be recreated and imagined. Excavating and rereading the ecological thoughts in British and American literary works can effectively exert the social functions and natural functions of literature, because "the greatest contribution of ecological criticism is the contribution to the earth's ecology, the contribution to nature, and the alleviation and elimination of ecology. The contribution of the crisis."

The English and American literature courses generally face the situation of class time reduction and content compression, and the nature of the literature course determines that it must be extended. By reading and enjoying the poems with nature as the theme and imagery, you can truly understand the function of nature as a human guide and nanny, experience the magnificence and greatness of nature, rethink the relationship between man and nature, and renew the true relationship that is cut by industrial civilization. . Modernist writers basically have the tendency of anti-modern civilization. Only in the blending with nature can people reveal the true perfect state, and the people under the constraints of industrial civilization are deformed and distorted. "The function of literature and criticism is not only limited to human beings, but also acts on non-humans through human beings and acts on the whole world." Literature is to awaken human sleeping souls through its linguistic charm and ideological connotation, enlighten people. Wisdom to achieve the integration of literature and society.

At present, ecological criticism has become a trend. Any literary work can be ecologically aestheticized. For some works and writers with outstanding ecological or anti-ecological thoughts, it seems that many fixed patterns have been formed. This kind of stereotyped thinking can inspire students, but it greatly limits the students' critical thinking and neglects the contradiction and complexity of each writer's and works' ideas. "Review and re-evaluation of ecological perspectives should objectively, historically and comprehensively examine traditional literary classics, avoiding isolation, simplification and partiality." As a guide for the classroom, teachers must be comprehensive and develop. Look at the problem. On the one hand, we must fully consider the 
creative context of the works, on the other hand, we must fully consider the multifaceted and contradictory nature of the author's thoughts. Classical literary works contain rich ideas. Teachers can't blindly understand the literary meaning and social value of the ecological interpretation. They can't break the rules and separate and simplify the works. They can't be bound by stereotypes. Look at the problem.

\section{Introducing Literary Criticism into the Conscious Creation and Cultural Life of Literature}

From the current domestic research, the ecological feminist literary criticism still only stays in the narrow field of criticism, does not have a conscious connection with literary creation, and does not actively influence literary creation; moreover, literary criticism does not go beyond the scope of literary space. The research and interpretation of some of the phenomena that remain in literary works have not touched the real space of human existence. Domestic ecofeminist literary criticism has limitations and prospects are limited.

In the process of teaching English and American literature, literary criticism should be actively introduced into the conscious creation and cultural life of literature. Through eco-feminist criticism, arousing students' love for the natural environment and female respect and attention, and stimulating the conscious creation of eco-feminist literary works, this criticism and the practice of creation are more closely related, from the true sense of nature and Women participate in social development on an equal footing, promote the harmony between adults and nature, men and women, and realize the ultimate concern of ecofeminist literary criticism. If we make rapid progress in this aspect, Chinese ecofeminist literary criticism will be at the forefront of Western countries and the world.

\section{Combining Multiple Literary Criticism Theories to Improve Teaching Results}

As a method of criticism, ecofeminist literary criticism is closely integrated with real life and guides people to pay attention to nature and women through literary works. The theory of eco-feminist literary criticism has been widely applied. At the same time of development, there are still some shortcomings: the study of critical theory is superficial, lacking depth and systemic; text interpretation is limited to a few classics, lacking breadth and reality; more Staying in the narrow and single field of literary criticism, failing to fully engage with literary creation, thus influencing and guiding literary creation; as a pluralistic literary criticism concept, the broadness, openness, cross-cutting and ecological feminism literary criticism Advantages such as interactivity have not been fully realized. In the actual English and American literature teaching process, it must be combined with other literary criticism theories to give full play to the overall advantages and improve the teaching effect. The combination of multiple critical theories in the teaching of English and American literature can also enhance students' ability to appreciate and recognize literary works, and improve their ability to analyze and solve problems. Appropriately integrating the results of literary criticism theory into teaching practice, and using corresponding critical theory to analyze different works, can cultivate students' ability to analyze problems from multiple angles, and greatly broaden students' research horizons. Specifically includes three theories:

First, the British and American new criticism, this is a practical criticism method, focusing on the literary nature of the work, focusing on the intrinsic meaning of the text, emphasizing the relationship between words and the whole context in the works; promoting the perusal of individual works, focusing on seeking The smallest difference in the meaning of a word, thus reflecting the meaning and tension produced by the difference, and then using paradox and irony to explain the tension and conflict in the work, and ultimately produce an aesthetic effect.

Second, structuralist criticism emphasizes the scientific and systematic study of the structure of literary works. Through the structural analysis of specific works, the potential laws within literature are sought. Structuralist criticism is applied to the teaching practice of English and American literature, helping students to find out the inherent laws and structural patterns of literature from 
specific texts, breaking the mystery of literary creation, combining the mining of textual meaning with the study of structural forms to achieve content and content. The unity of form.

Third, psychoanalytic criticism applies Sigmund Freud's psychoanalysis and other modern psychological theories to literary criticism, and analyzes the conflicts between human beings, self and superego in literary texts. Influenced by Freud's psychoanalytic theory and Bergson's psychological time, from the traditional description of the external world to the mining of the unconscious field of human beings. The use of psychoanalytic criticism can more accurately grasp the pulse of modern British and American literature.

Fourth, reader response theory has completely changed the relationship between readers, texts and authors. The relationship between the reader and the text is interactive, and the reader is the creator of the meaning of the text. Leaving the reader's creative reading activities, the meaning of the text will be exhausted. Reader's reaction theory breaks the old literary concept. In the process of teaching, the teacher-centered teaching mode should be changed. On the basis of providing students with the necessary knowledge and information, students-centered classroom teaching activities should be carried out to guide students to play. Imagination, using personal life experience and aesthetic experience, has a personally creative interpretation of the work.

\section{Acknowledgement}

This work is supported by social science fund project of Liaoning province: Westward Ecofeminism Literary Criticism and Its Reference and Innovation of Discourse Strategy (L16BWW001); Innovation Paths on Promote the Outstanding National Traditional Culture Going Out under the "One Belt And One Road" Construction (L18DMZ001).

\section{References}

[1] R. F. Ma, "The perspective of ecocriticism in the teaching of English and American literature," Theory and Practice of Contemporary Education, vol. 4, no. 1, pp. 115-117, 2014.

[2] X. D. Liang, "Western Literary Critical Theory's Applications in Teaching English Literature," Journal of Chongqing University of Arts and Sciences (Social Sciences Edition), vol. 5, no. 6, pp. 92-95, 2006.

[3] X. F. Nie, Q. F. Fu, "The significance and role of eco literary criticism in the teaching of British and American literature," Journal of Yichun College, vol. 33, no. 7, pp. 184-185, 2011.

[4] L. Ma, Y. M. Cao, "The teaching of British and American literature from the perspective of ecocriticism," Journal of Educational Institute of Jilin Province, vol. 31, no. 2, pp. 97-99, 2015.

[5] J. Liu, "The teaching of British and American Literature under the theory of literary criticism," Home Drama, vol. 28, no. 12, pp. 149-151, 2018.

[6] J. Wang, "Literature teaching from the perspective of female literary criticism," Today's Massmedia, vol. 26, no. 1, pp. 45-46, 2017.

[7] X. Liu, "Female and Nature: Study on the Eco-feminist Literary Criticism," Master's degree of Huazhong Normal University, 2014. 